\title{
OPEN Possible proteomic biomarkers for the detection of pancreatic cancer in oral fluids
}

\author{
O. Deutsch ${ }^{1,7}$, Y. Haviv ${ }^{2,7}$, G. Krief ${ }^{1}$, N. Keshet ${ }^{2}$, R. Westreich ${ }^{3,4}$, S. M. Stemmer ${ }^{5}$, B. Zaks ${ }^{1}$, \\ S. P. Navat ${ }^{1}$, R. Yanko' ${ }^{2}$, O. Lahav ${ }^{1}$, D. J. Aframian ${ }^{2,7}$ \& A. Palmon ${ }^{1,6,7 凶}$
}

The $80 \%$ mortality rate of pancreatic-cancer (PC) makes early diagnosis a challenge. Oral fluids (OF) may be considered the ultimate body fluid for non-invasive examinations. We have developed techniques to improve visualization of minor OF proteins thereby overcoming major barriers to using OF as a diagnostic fluid. The aim of this study was to establish a short discriminative panel of OF biomarkers for the detection of PC. Unstimulated OF were collected from PC patients and controls $(n=30)$. High-abundance-proteins were depleted and the remaining proteins were analyzed by twodimensional-gel-electrophoresis and quantitative dimethylation-liquid-chromatography-tandem mass-spectrometry. Label-free quantitative-mass-spectrometry analysis (qMS) was performed on 20 individual samples $(n=20)$. More than 100 biomarker candidates were identified in OF samples, and 21 had a highly differential expression profile. qMS analysis yielded a ROC-plot AUC value of 0.91 with $90.0 \%$ sensitivity and specificity for a combination of five biomarker candidates. We found a combination of five biomarkers for PC. Most of these proteins are known to be related to PC or other gastric cancers, but have never been detected in OF. This study demonstrates the importance of novel OF depletion methodologies for increased protein visibility and highlights the clinical applicability of OF as a diagnostic fluid.

\author{
Abbreviations \\ OF Oral fluids \\ PC Pancreatic cancer
}

Pancreatic cancer (PC) often remains undetected until the late stages of the disease. Each year approximately 37,000 Americans are diagnosed with PC, furthermore, 33,000 Americans and more than 42,000 Europeans die from pancreatic cancer annually ${ }^{1}$. PC was the 4th leading caner type for estimated deaths in the USA in 2012 and $2013^{2-4}$.

The median survival time for PC is nine to 12 months with an overall 5 -year survival rate of $3 \%$. The high mortality rate is due in part to the fact more than $50 \%$ of patients with PC have metastatic disease at the time of diagnosis. The 50\% recurrence of PC following surgical removal, suggests that PC is relatively refractory to current treatments.

No specific tumor marker for the diagnosis of PC has been identified, complicating early diagnosis. Therefore, extensive genomic, transcriptomic, and proteomic studies are being performed to identify candidate markers by employing high-throughput systems capable of large cohort screening. Currently, early detection of pancreatic cancer in high-risk patients is done using highly invasive means (Endoscopic ultrasound combined with fineneedle-aspiration). These methods cause discomfort, require an expert team and are very expensive, making them useless as screening tools. The lack of a single diagnostic marker suggests that only a combination of biomarkers

${ }^{1}$ Institute of Dental Sciences, Faculty of Dental Medicine, The Hebrew University of Jerusalem, Jerusalem, Israel. 'Salivary Gland Clinic and Saliva Diagnostic Laboratory, Department of Oral Medicine, Sedation and Maxillofacial Radiology, Sjogren's Syndrome Center, Hadassah Medical Center, The Hebrew University of Jerusalem, Jerusalem, Israel. ${ }^{3}$ Department of Internal Medicine B, Soroka Medical Center, Beer-Sheva, Israel. ${ }^{4}$ Faculty of Health Sciences, Ben-Gurion University of the Negev, Beer-Sheva, Israel. ${ }^{5}$ Rabin Medical Center, Davidoff Center, Petach Tiqwa, Affiliated to the Sackler Faculty of Medicine, Tel Aviv University, Tel Aviv, Israel. ${ }^{6}$ Department of Oral Medicine, Sedation and Maxillofacial Imaging, Faculty of Dental Medicine, Hebrew University - Hadassah, Jerusalem, Israel. ${ }^{7}$ These authors contributed equally: O. Deutsch, Y. Haviv, D. J. Aframian and A. Palmon ${ }^{\varpi}$ email: yaronha@hadassah.org.il 
will be able to provide the appropriate combination of high sensitivity and specificity. Biomarker discovery using novel technologies can improve prognostic upgrading and pinpoint new molecular targets for innovative therapy.

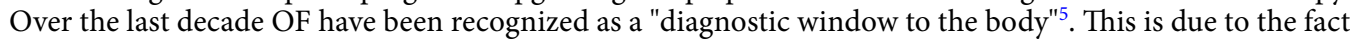
that despite the apparent low degree of overlap between OF and plasma, the distribution found across Gene Ontological categories, such as molecular function, biological processes, and cellular components, is very similar ${ }^{6}$.

Many centers, including our department, have taken advantage of the non-invasive access to this readily available body fluid. Furthermore the composition of OF is known and therefore fluctuations can be used to monitor diseases and physiological changes ${ }^{7}$. The positive aspects of OF compared to serum as a diagnostic fluid for practitioners include simple collection (of adequate volumes), storage and shipment. Procurement is also safer than venipuncture, limiting exposure to infectious agents. The non-invasive, painless collection reduces fear and enhances compliance when repeated samples are needed over time. The non-clotting nature of the fluid makes it ideal for diagnostic purposes ${ }^{8}$.

Analysis of OF using proteomics has been hindered by the presence of high abundant proteins such as salivary alpha amylases (sAA) $)^{9-12}$ albumins (alb) ${ }^{13}$ and immunoglobulins (Ig) ${ }^{12,13}$ which conceal or reduce the separation sensitivity of other proteins.

There are two main advantages to high abundant protein depletion followed by 2DE: (i) gel resolution is increased because the levels of the low abundant proteins in the proteomic map are relatively higher and (ii) important low abundant proteins are revealed when the overlapping high abundant protein spots are removed. Low abundant proteins can also be exposed by using qMS.

We have developed and successfully used techniques to remove the high abundant proteins in OF, thereby improving protein visualization ${ }^{14-16}$. We hypothesize that OF composition will be altered by pancreatic cancer. The similarity of the structure of the salivary and pancreatic glands may cause the salivary glands to function as a biological amplifier and to produce proteins in response to PC which will be detectable in OF. This phenomenon has been reported in breast cancer patients, (the structure of the mammary glands is also similar to the salivary glands). C-erb-b2 a breast cancer marker was produced by the salivary glands and detected in the saliva of breast cancer patients ${ }^{17}$.

The aim of this study was to identify and develop an early detection assay for PC based on OF, to characterize OF proteins following removal of the high abundance proteins, and to identify candidate biomarkers for PC.

\section{Materials and methods}

Ethical approval. The OF accumulation protocol was approved by the Ethical Committee, Rabin Medical Center, Beilinson Hospital, Request No. 0053-09-RMC. Informed consent was obtained according to the instructions of the Ethical Committee. All procedures were carried out in accordance with relevant guidelines and regulations.

OF collection, patients and healthy volunteers. Unstimulated OF flow was collected for 5 min using the spitting method ${ }^{18}$ into pre-calibrated tubes. All participants refrained from eating, drinking and brushing their teeth $1 \mathrm{~h}$ prior to saliva collection. Patients did not take their medications, including sialagogues, before saliva collection.

Volunteers rested for 10 min before saliva collection, sitting in an upright position and in a quiet room and were asked not to speak or leave the room until after the saliva was collected. Saliva samples were immediately placed on ice and then centrifuged at $14,000 \mathrm{~g}$ for $20 \mathrm{~min}$ at $4{ }^{\circ} \mathrm{C}$ to remove insoluble materials, cell debris and food remnants. The supernatant of each sample was collected and protein concentration was determined using the Bio-Rad Bradford protein assay (Bio-Rad, Hercules, CA, USA) as previously described ${ }^{19}$.

OF were collected from 31 males; 15 PC patients and 16 healthy, age matched controls. Controls did not take any medications known to cause xerostomia (supplementary data A), had no complaints of oral dryness and no evidence oral mucosal diseases was detected following examination. 2 patients in the PC group were undergoing chemotherapy at the time of collection and were therefore excluded from the OF pool. Salivary flow rate was calculated. OF samples were divided into two groups: (1) for to 2DE and Demethylation MS analysis (described below), samples were pooled according to the amount of total protein in each individual sample. 2) For label-free qMS, individual samples were used.

SAA affinity removal. Amylase was removed from the pooled OF using an amylase removing device. 600 $\mu \mathrm{L}$ of water was hand pressed $(20 \mathrm{~s})$ through the device to moisturize the substrate. Thereafter, $1 \mathrm{~mL}$ of pooled OF (in two aliquots of $500 \mu \mathrm{L}$ ) was hand pressed and filtered $(120 \mathrm{~s})$ through the amylase removing device. The resultant $1 \mathrm{~mL}$ of filtrated OF was amylase-free, as previously described ${ }^{14}$.

Alb and IgGs removal, capturing and elution. In order to remove alb and IgGs the ProteoPrep Immunoaffinity alb and IgG Depletion Kit (Sigma-Aldrich, St Louis, MO, USA) were used as previously described ${ }^{15}$ Protein concentration was measured again as before, using the Bio-Rad Bradford protein assay (Bio-Rad, Hercules, CA, USA) ${ }^{19}$.

The triple depleted OF were divided to 2 tubes for $2 \mathrm{DE}$ and quantitative MS analysis and frozen at $-80{ }^{\circ} \mathrm{C}$ and lyophilized overnight. Sediments (products (deposits) of lyophilization processes) for 2DE were dissolved in $7 \mathrm{M}$ urea, $2 \mathrm{M}$ thiourea and $4 \% 3$-[(3-cholamidopropyl) dimethylammonio]-1-propane-sulfonate (CHAPS) and stored at $-20^{\circ} \mathrm{C}$ until analysis.

Two-dimensional sodium dodecyl sulfate polyacrylamide gel electrophoresis (2DE). For analytical gels, $100 \mu \mathrm{g}$ of protein were rehydrated then subjected to isoelectrofocusing in $18 \mathrm{~cm}$ long second dimen- 
sion gels, $\mathrm{pH} 3-10 \mathrm{NL}$ as previously described ${ }^{20}$. To prepare the gel strips for separation in the second dimension they were soaked twice for $15 \mathrm{~min}$ in an SDS-PAGE equilibration buffer as previously described ${ }^{14}$. For the second dimension, strips were embedded in $0.5 \% \mathrm{w} / \mathrm{v}$ agarose containing a trace of bromophenol blue and loaded onto hinged spacer plates $(20 \mathrm{~cm} \times 20.5 \mathrm{~cm}$; Bio-Rad, Hercules, CA, USA $)$ using $9.5-16.5 \%$ SDS polyacrylamide gradient gel electrophoresis. The same running and staining apparatus at a constant current of $30 \mathrm{~mA}$ per gel at $10{ }^{\circ} \mathrm{C}$ was used for all samples. Gels were silver stained with SilverQuest kit (Invitrogen, Carlsbad, CA, USA).

Imaging and statistical analysis. Gels were scanned using a computer GS-800 calibrated densitometer (Bio-Rad, Hercules, CA, USA) and spots were detected and quantified using PDQuest software V 6.2.0 (BioRad, Hercules, CA, USA). In order to overcome several of the known limitations of 2D gel analysis that occur as a result of gel to gel variation, and also variability in staining ${ }^{14}$, all samples were run simultaneously for the first and second dimensions. Normalization with PDQuest was performed using the total density in image method to semi-quantify spot intensities and to minimize staining variation between gels ${ }^{14}$.

2DE Mass-spectrometry (MS) identification. For MS identification, a 2DE containing $100 \mu \mathrm{g}$ of protein was prepared and fixed in 50\% (v/v) ethanol, $12 \%(\mathrm{v} / \mathrm{v})$ acetic acid for $2 \mathrm{~h}$. Proteins were visualized by staining with a SilverQuest staining kit for MS compatible silver staining (SilverQuest, Invitrogen, Carlsbad, CA, USA). Electrophoretically separated spots were excised from the gels, and in-gel reduced (10 mM Dith-9 iothreitol, incubated at $6{ }^{\circ} \mathrm{C}$ for $30 \mathrm{~min}$ ), alkylated ( $10 \mathrm{mM}$ iodoacetamide, at room temperature for $\left.30 \mathrm{~min}\right)$ and proteolyzed with trypsin (overnight at $37^{\circ} \mathrm{C}$ using modified trypsin, Promega at a 1:100 enzyme-to-substrate ratio). The resulting tryptic peptides were resolved by reversed-phase chromatography on $0.1 \cdot 200-\mathrm{mm}$ fused silica capillaries (J\&W, $100 \mu \mathrm{m}$ ID) packed with Everest reversed phase material (Grace Vydac, CA, USA). The peptides were eluted with a 45 min gradient of 5 to $95 \%(\mathrm{v} / \mathrm{v})$ of acetonitrile with $0.1 \%(\mathrm{v} / \mathrm{v})$ formic acid in water at flow rates of $0.4 \mathrm{ll} \mathrm{min.} \mathrm{Mass} \mathrm{spectrometry} \mathrm{was} \mathrm{performed} \mathrm{by} \mathrm{an} \mathrm{ion-trap} \mathrm{MS} \mathrm{(Orbitrap;} \mathrm{Thermo)} \mathrm{in} \mathrm{a} \mathrm{posi-}$ tive mode using a repetitively full MS scan followed by collision induced dissociation (CID) of the five most dominant ions selected from the first MS scan. The MS data were clustered and analyzed using Sequest software (version 3.31; J. Eng and J. Yates, University of Washington and Finnegan, San Jose, USA) and Pep-Miner ${ }^{21}$ searching against the human part of the Uniprot database (2014_03, https://www.uniprot.org/). The results were filtered according to the Xcorr value (1.5 for singly charged peptides, 2.2 for doubly charged peptides and 3 for triply charged peptides).

Quantitative mass-spectrometry (MS). Protein extraction and proteolysis. The proteins in $8 \mathrm{M}$ Urea were reduced with $2.8 \mathrm{mM}$ DTT $\left(60^{\circ} \mathrm{C}\right.$ for $\left.30 \mathrm{~min}\right)$, modified with $8.8 \mathrm{mM}$ iodoacetamide in $100 \mathrm{mM}$ ammonium bicarbonate (room temperature for $30 \mathrm{~min}$ ) and digested in $2 \mathrm{M}$ Urea, $25 \mathrm{mM}$ ammonium bicarbonate with modified trypsin (Promega) at a 1:50 enzyme-to-substrate ratio, overnight at $37^{\circ} \mathrm{C}$. In order to achieve full cleavage, a second $4 \mathrm{~h}$ digestion was performed at $37^{\circ} \mathrm{C}$.

Demethylation MS analysis. As described previously by Krief et al. $^{7}$, the resulting peptides were desalted using $\mathrm{C} 18$ Stage tips, dried and re-suspended in $50 \mathrm{mM}$ Hepes ( $\mathrm{pH}$ 6.4). Labeling by Dimethylation was done in the presence of $100 \mathrm{mM} \mathrm{NaCBH}_{3}$ (Sterogene cat\#9704 1M), by adding Light Formaldehyde (35\% Frutarom cat $\# 5551810,12.3 \mathrm{M})$ to the pooled control sample, and Heavy Formaldehyde $(20 \% \mathrm{w} / \mathrm{w}$, Cambridge Isotope laboratories cat\#CDLM-4599-16.5M) to the pooled PC sample to a final concentration of $200 \mathrm{mM}$. Following $1 \mathrm{~h}$ of incubation at room temperature the $\mathrm{pH}$ was raised to 8 and the reaction was incubated for another hour at room temperature. Neutralization was done with $25 \mathrm{mM}$ ammonium bicarbonate for $30 \mathrm{~min}$, and equal amounts of the light and heavy peptides were mixed, cleaned on a C18 stage tip, dried and re-suspended in $0.1 \%$ formic acid.

Peptides were resolved by reverse-phase chromatography on $0.075 \times 200$-mm fused silica capillaries (J\&W) packed with Reprosil reverse phase material (Dr. Maisch GmbH, Germany). The peptides were eluted with linear $215 \mathrm{~min}$ gradients of 7 to $40 \%$ and then for $8 \mathrm{~min}$ at $95 \%$ acetonitrile with $0.1 \%$ formic acid in water at flow rates of $0.25 \mu \mathrm{l} / \mathrm{min}$. Mass spectrometry was performed using an ion-trap mass spectrometer (Orbitrap, Thermo) in a positive mode using a repetitively full MS scan followed by collision induced dissociation (CID) of the 7 most dominant ions selected from the first MS scan.

The MS data was analyzed using Sequest 3.31 software (J. Eng and J. Yates, University of Washington and Finnegan, San Jose) searching the human part of the NCBI-NR database. Quantitation was performed using the PepQuant algorithm of Bioworks and "in house" software.

Label free MS analysis. 20 individual samples (from 10 PC patients and 10 healthy volunteers) were analyzed using Label free analysis following the depletion of high abundance proteins. The tryptic peptides were desalted using C18 tips, dried and re-suspended in $0.1 \%$ formic acid. The peptides were resolved by reverse-phase chromatography on $0.075 \times 200$ - $\mathrm{mm}$ fused silica capillaries $(\mathrm{J} \& W)$ packed with Reprosil reversed phase material (Dr Maisch GmbH, Germany). The peptides were eluted as described above. A wash run and one blank injection were performed between the samples to make sure there was no cross contamination ${ }^{7}$.

The MS data was analyzed using MaxQuant 1.2.2.5 software (Mathias Mann's group) searching against the human section of the Uniprot database and quantified by label free analysis using the same software. Statistical analysis was done using Perseus software (Mathias Mann's group). 
Bio-statistical analysis. Dr. Yoav Smith (Head of the Genomic Data Analysis Unit, The Hebrew University, Jerusalem) was our consultant for the analysis. Briefly, label-free qMS results were initially analyzed utilizing Matlab software R2013a (The MathWorks, Inc. USA). Data was then presented in a Volcano plot using the vertical axis for the p-values and the horizontal axis for the $\log 2$ ratio values. By using a threshold of less than 0.05 for the p-values, and a fold change of + or -2 for the absolute $\log 2$ ratios, proteins with the largest statistically significant expression change were chosen. Furthermore, for the combined protein group the predicted probability for each subject was obtained and was used to construct receiver operating characteristic (ROC) curves. The standard error of the area under the curve (AUC) value and the 95\% confidence interval (CI) for the ROC curve were computed as previously described ${ }^{22}$. The sensitivity and specificity for the combined biomarkers were estimated by identifying the cutoff-point of the predicted probability that yielded the highest sum of sensitivity and specificity.

\section{Results}

The mean age of the 15 PC patients was $65.7 \pm 13.24$ years, and the mean age of the 16 healthy age-matched controls was $56.5 \pm 3.3$ years. The average time from PC diagnosis to OF collection was $\sim 7$ months.

$72 \%$ of the patients were diagnosed with stage IV and the rest with stage III. All the PC patients took medications regularly, and their tendency to cause xerostomia was checked (supplementary data A), only 2 patients used medicines known to cause dry mouth in more than $10 \%$ of individuals.

The study was divided into sections: 1 . Proteomic analysis on pooled samples using 2DE and dimethylationqMS. 2. Analysis of individual samples using label-free qMS.

Dimethylation MS analysis of pooled PC and control samples. Dimethylation followed by LCMS/MS of PC and control OF samples exposed 182 proteins (supplementary data B). 21 proteins showed an extended differential profile with a 3 to 50 -fold change in expression. 37 proteins had a 2 to threefold expression change (see Table 1 for details). Table $1 \mathrm{~A}$ refers to publications implicating 19 of our 21 identified proteins as biomarker candidates for PC or other cancers. None of these proteins has ever been detected in OF of PC patients.

2DE and MS analysis of pooled PC and control samples. 2DE of pooled triple-depleted OF samples from healthy controls (Fig. 1A) and PC patients (Fig. 1B) was performed. PDQuest analysis revealed 360 protein spots, and 72 had an expression change of more than threefold. 15 spots with expression changes greater than fivefold were chosen for MS analysis. Only spots identified in both maps were further analyzed by MS (supplementary data $\mathrm{C}$ ). Of the twenty proteins identified, 12 were newly identified; Ig kappa chain V-I region AG (P01593), Ig kappa chain V-I region DEE (P01597), Polymeric immunoglobulin receptor P01833, Ig alpha-1 chain C region (P01876), Cystatin-B (P04080), Protein disulfide-isomerase (P07237), Leukocyte elastase inhibitor (P30740), Beta-2-microglobulin (P61769), Fatty acid-binding protein, epidermal (Q01469), Serpin(Q9UIV8), Tumor necrosis factor ligand superfamily member 13B (Q9Y275), IgGFc-binding protein (Q9Y6R7). Of the 8 proteins also found in the qMS results, 5 had a similar trend; Ig kappa chain $\mathrm{C}$ region (P01834), Ig mu chain $\mathrm{C}$ region (P01871), Serum albumin (P02768), Leukotriene A-4 hydrolase (P09960), Hemoglobin subunit beta (P68871). The remaining 3 showed an opposite trend; Ig kappa chain V-III region SIE (P01620), Zinc-alpha2-glycoprotein (P25311), Hemoglobin subunit beta (P68871) and Lipocalin-1 (P31025).

Label free qMS on individual samples. This extensive examination led to the identification of 480 proteins. MS results show the relative expression profile of the proteins in each sample. An average expression ratio was calculated for each protein. 71 proteins were down regulated by more than twofold in PC samples, among them 34 by more than threefold. 92 proteins were up regulated by more than twofold, out of them 46 by more than threefold. The subsequent statistical analysis ( $t$ test, $p$ value $<0.05$ ), showed 39 proteins with an average change in expression profile of more than twofold. The proteins were grouped according to the number of subjects in which they were found; less than 6 subjects and more than 6 subjects. For example, S100-A9 was found in OF samples of all subjects, and decreased significantly $(p<0.05)$ by more than threefold in PC patients [Table 2, Fig. 2A].

From the 39 statistically significant highly differentiated proteins, 8 had similar trends to those noted in the pooled sample results, including; Glyceraldehyde-3-phosphate dehydrogenase (P04406), S100-A8 (P05109), S100-A9 (P06702), Disulfide-isomerase (P07237), Zinc-alpha-2-glycoprotein (P25311), Cornulin (Q9UBG3), Apolipoprotein A-I (P02647), L-lactate dehydrogenase B chain (P07195).

Interestingly, Zinc-alpha-2-glycoprotein (P25311), showed an increased expression profile in the individual qMS whereas the in the results of the qMS of pooled samples it showed an opposite trend. Another controversial protein was Lipocalin-1 (P31025) in which the individual MS supported the results of the 2DE showing an average increase of more than 3.5-fold in PC patients, but the changes in the MS were not statistically significant.

Bio-statistical analysis. In order to determine a short panel of discriminative biomarkers, label free qMS results were bio-statistical analyzed utilizing Matlab software R2013a (The MathWorks, Inc, USA). Data was presented in a Volcano plot using the vertical axis (Fig. 2B).

The Biostatistical analysis revealed five highly discriminative proteins; Cytokeratin-14 (P02533), Lactoperoxidase (P22079), Cytokeratin-16 (P08730), Cytokeratin-17 (Q04695) and Peptidyl-prolyl cis-trans isomerase B (P23284).

To further examine the clinical utility of this combination of biomarkers for PC detection, an ROC curve was built. This model yielded a ROC-plot AUC value of 0.910 (95\% CI, 0.714 to $1.000 ; p<0.000001)$ with 


\begin{tabular}{|c|c|c|c|c|c|c|c|c|c|c|}
\hline \multirow[b]{2}{*}{ Serial no } & \multirow[b]{2}{*}{\begin{tabular}{|l|} 
Protein \\
identification
\end{tabular}} & \multirow[b]{2}{*}{ Accession no } & \multirow[b]{2}{*}{ MW (Da) } & \multirow[b]{2}{*}{$\begin{array}{l}\text { Matched } \\
\text { peptides }\end{array}$} & \multirow[b]{2}{*}{\begin{tabular}{|l|} 
Average Ratio \\
PC/C
\end{tabular}} & \multirow[b]{2}{*}{ Sample origin } & \multirow[b]{2}{*}{ Not Identified } & \multirow[b]{2}{*}{ Not Identified } & \multicolumn{2}{|c|}{ Previously identified } \\
\hline & & & & & & & & & $\begin{array}{l}\text { PC } \\
\text { biomarkers }\end{array}$ & $\begin{array}{l}\text { Other cancer } \\
\text { biomarkers }\end{array}$ \\
\hline \multicolumn{11}{|c|}{1} \\
\hline 1 & Histone $\mathrm{H} 4$ & P62805 & 11,360 & 3 & 0.02 & $\begin{array}{l}\text { HNSCC*}, \\
\text { Saliva }\end{array}$ & & & & {$[43,44]$} \\
\hline 2 & $\begin{array}{l}\text { Histone H2B } \\
\text { type 1-B }\end{array}$ & P33778 & 13,942 & 2 & 0.03 & $\begin{array}{l}\text { Pancreatic } \\
\text { tumor tissue }\end{array}$ & & & {$[45]$} & \\
\hline 3 & \begin{tabular}{|l|} 
6-phospho- \\
gluconate \\
dehydrogenase, \\
decarboxylat- \\
ing
\end{tabular} & P52209 & 53,106 & 2 & 0.04 & FNA of PTC ${ }^{\star *}$ & & & & {$[46]$} \\
\hline 4 & $\begin{array}{l}\text { Basic salivary } \\
\text { proline-rich } \\
\text { protein } 2 \\
\text { precursor }\end{array}$ & P02812 & 40,775 & 2 & 0.05 & Saliva & & & & {$[44]$} \\
\hline 5 & $\begin{array}{l}\text { Histone H2B } \\
\text { type 1-A }\end{array}$ & Q96A08 & 14,159 & 2 & 0.06 & HNSCC ${ }^{*}$ & & & & {$[43]$} \\
\hline 6 & $\begin{array}{l}\text { Azurocidin } \\
\text { precursor }\end{array}$ & P20160 & 26,869 & 3 & 0.07 & & $\mathrm{x}$ & $\mathrm{x}$ & & \\
\hline 7 & $\begin{array}{l}\text { Apolipoprotein } \\
\text { A-I precursor }\end{array}$ & P02647 & 30,759 & 7 & 0.08 & $\begin{array}{l}\text { Biological } \\
\text { sample }\end{array}$ & & & & {$[27]$} \\
\hline 8 & $\begin{array}{l}\text { Alpha-amylase } \\
1 \text { precursor }\end{array}$ & P04745 & 57,731 & 31 & 0.16 & Saliva & & & & {$[44]$} \\
\hline 9 & $\begin{array}{l}\text { Myeloperoxi- } \\
\text { dase precursor }\end{array}$ & P05164 & 83,815 & 9 & 0.16 & Blood & & & {$[28]$} & \\
\hline 10 & $\begin{array}{l}\text { Protein } \\
\text { S100-A8 }\end{array}$ & P05109 & 10,828 & 6 & 0.19 & $\begin{array}{l}\text { Human } \\
\text { Pancreatic } \\
\text { Cell-line }\end{array}$ & & & {$[30]$} & \\
\hline 11 & \begin{tabular}{|l|} 
Transthyretin \\
precursor
\end{tabular} & P02766 & 15,877 & 6 & 0.22 & Serum & & & {$[29]$} & \\
\hline 12 & $\begin{array}{l}\text { Lipocalin-1 } \\
\text { precursor }\end{array}$ & P31025 & 19,238 & 12 & 0.23 & $\begin{array}{l}\text { Human } \\
\text { Pancreatic } \\
\text { Cell-line }\end{array}$ & & & {$[30]$} & \\
\hline 13 & \begin{tabular}{|l} 
Protein \\
S100-A9
\end{tabular} & P06702 & 13,234 & 7 & 0.24 & $\begin{array}{l}\text { Biological } \\
\text { sample, Saliva }\end{array}$ & & & {$[47]$} & {$[44]$} \\
\hline 14 & $\begin{array}{l}\text { Short palate, } \\
\text { lung and nasal } \\
\text { epithelium } \\
\text { carcinoma- } \\
\text { associated } \\
\text { protein 2 } \\
\text { precursor }\end{array}$ & Q96DR5 & 26,995 & 6 & 0.24 & Saliva & & & & {$[48]$} \\
\hline 15 & $\begin{array}{l}\text { Hemoglobin } \\
\text { subunit alpha }\end{array}$ & P69905 & 15,248 & 9 & 0.25 & $\begin{array}{l}\text { Pancre- } \\
\text { atic tumor } \\
\text { tissue,Saliva }\end{array}$ & & & {$[45]$} & {$[44]$} \\
\hline 16 & $\begin{array}{l}\text { Small proline- } \\
\text { rich protein } 2 \mathrm{~A}\end{array}$ & P35326 & 7960 & 3 & 0.25 & & $\mathrm{x}$ & $\mathrm{x}$ & & \\
\hline 17 & $\begin{array}{l}\text { Hemoglobin } \\
\text { subunit delta }\end{array}$ & P02042 & 16,045 & 2 & 0.26 & \begin{tabular}{|l} 
Tissue and \\
Serum
\end{tabular} & & & & {$[49]$} \\
\hline 18 & Transketolase & P29401 & 67,835 & 11 & 3.18 & $\begin{array}{l}\text { pancreatic } \\
\text { ductal tissue }\end{array}$ & & & {$[31]$} & \\
\hline 19 & $\begin{array}{l}\text { Keratin, type I } \\
\text { cytoskeletal } 10\end{array}$ & P13645 & 59,475 & 2 & 4.57 & $\begin{array}{l}\text { Pancreatic } \\
\text { cancer tissue }\end{array}$ & & & {$[50]$} & \\
\hline 20 & $\begin{array}{l}\text { Hemopexin } \\
\text { precursor }\end{array}$ & P02790 & 51,643 & 13 & 4.99 & Plasma, Saliva & & & {$[32]$} & {$[44]$} \\
\hline 21 & \begin{tabular}{|l} 
Alpha-2-mac- \\
roglobulin \\
precursor
\end{tabular} & P01023 & 163,174 & 41 & 8.06 & Plasma, Saliva & & & & {$[44,51]$} \\
\hline Serial No & $\begin{array}{l}\text { Protein } \\
\text { Identification }\end{array}$ & Accession No & MW (Da) & Peptides No & \begin{tabular}{|l} 
avg Ratio \\
(Patient/ \\
Healthy)
\end{tabular} & & & & & \\
\hline \multicolumn{11}{|l|}{ B } \\
\hline 1 & $\begin{array}{l}\text { Fibrinogen } \\
\text { alpha chain } \\
\text { precursor }\end{array}$ & P02671 & 94,914 & 5 & 0.31 & & & & & \\
\hline 2 & \begin{tabular}{|l|}
$\begin{array}{l}\text { Serum albumin } \\
\text { precursor }\end{array}$ \\
\end{tabular} & P02768 & 69,322 & 14 & 0.31 & & & & & \\
\hline 3 & $\begin{array}{l}\text { Hemoglobin } \\
\text { subunit beta }\end{array}$ & P68871 & 15,988 & 20 & 0.33 & & & & & \\
\hline \multicolumn{11}{|l|}{ Continued } \\
\hline
\end{tabular}




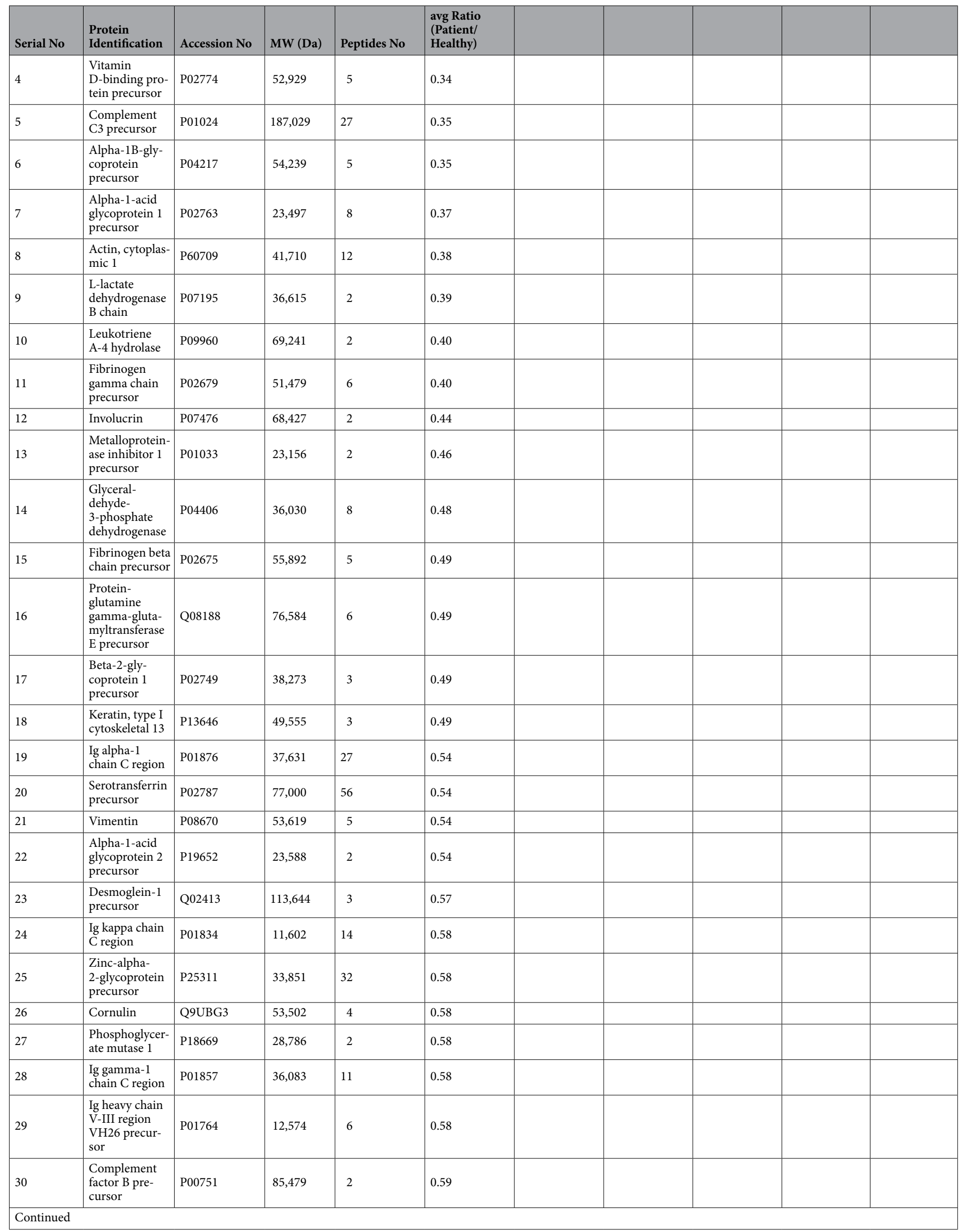




\begin{tabular}{|l|l|l|l|l|l|l|l|l|l|}
\hline Serial No & $\begin{array}{l}\text { Protein } \\
\text { Identification }\end{array}$ & Accession No & MW (Da) & Peptides No & $\begin{array}{l}\text { avg Ratio } \\
\text { (Patient/ } \\
\text { Healthy) }\end{array}$ & & & & \\
\hline 31 & $\begin{array}{l}\text { Aldehyde } \\
\text { dehydrogenase, } \\
\text { dimeric NADP- } \\
\text { preferring }\end{array}$ & P30838 & 50,347 & 3 & 0.60 & & & \\
\hline 32 & $\begin{array}{l}\text { Cystatin-S } \\
\text { precursor }\end{array}$ & P01036 & 16,204 & 10 & 1.91 & & & \\
\hline 33 & $\begin{array}{l}\text { Ig kappa chain } \\
\text { V-III region } \\
\text { SIE }\end{array}$ & P01620 & 11,768 & 6 & 1.94 & & & \\
\hline 34 & $\begin{array}{l}\text { Keratin, type II } \\
\text { cytoskeletal 1 }\end{array}$ & P04264 & 65,978 & 4 & 2.15 & & & \\
\hline 35 & $\begin{array}{l}\text { Keratin, type II } \\
\text { cytoskeletal 2 } \\
\text { epidermal }\end{array}$ & P35908 & 65,825 & 4 & 2.29 & & & \\
\hline 36 & $\begin{array}{l}\text { Alpha- } \\
\text { actinin-1 }\end{array}$ & P12814 & 102,993 & 4 & 2.49 & & & \\
\hline 37 & $\begin{array}{l}\text { Prolactin- } \\
\text { inducible pro- } \\
\text { tein precursor }\end{array}$ & P12273 & 16,562 & 10 & 2.59 & & & \\
\hline
\end{tabular}

Table 1. Proteins identified by Dimethylation MS analysis of pooled PC and control samples. A. Highly differentiated expression profile (above threefold). B 2 to threefold expression profile differences. ${ }^{*}$ NSCCHuman Head-and-Neck Squamous Cell Carcinomas tissue; ${ }^{*}$ FNA of PTC-Fine Needle Aspiration of Papillary Thyroid Cancer.
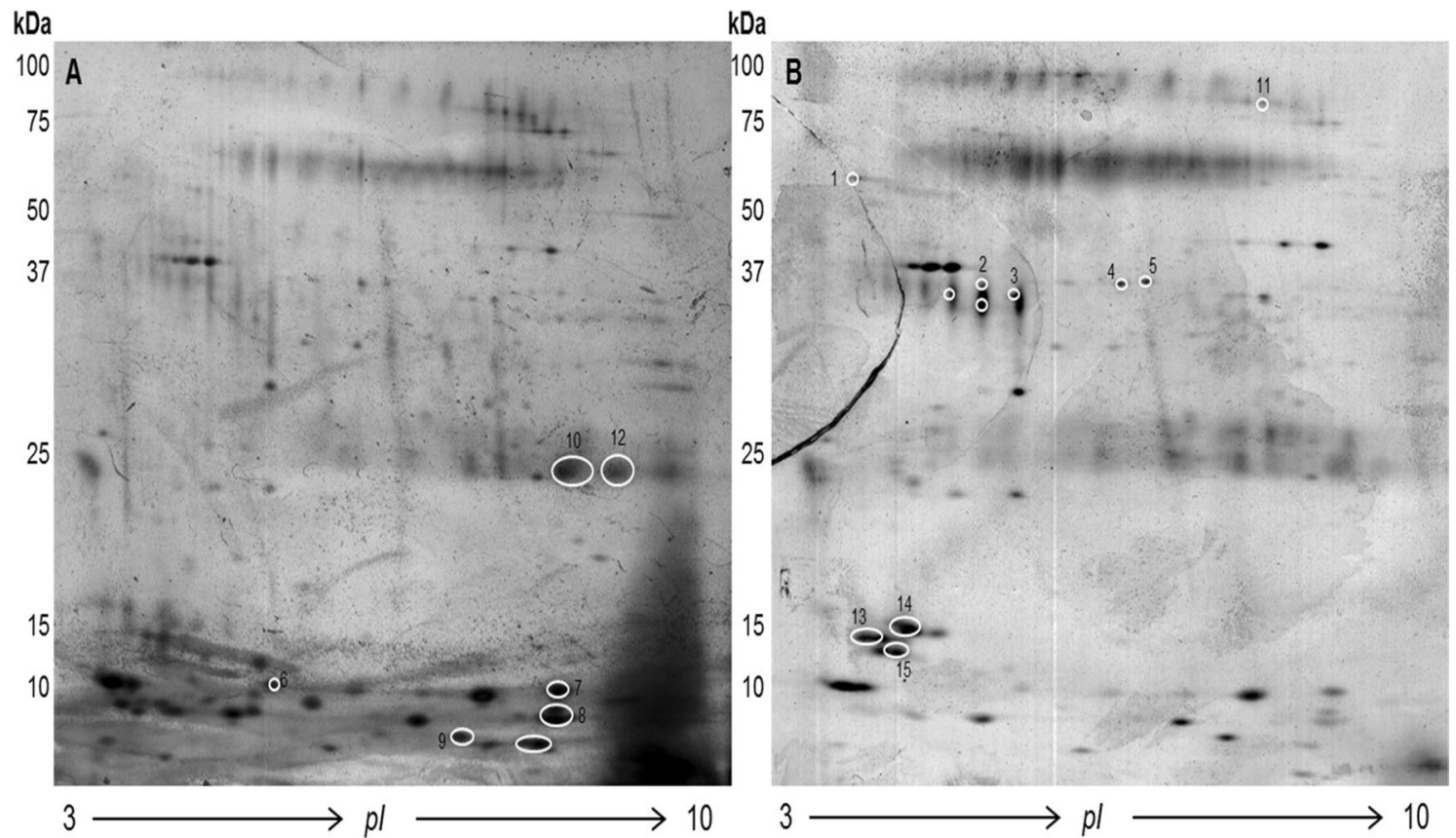

Figure 1. Silver-stained 2DE gels of pooled oral fluid samples after triple depletion $(100 \mu \mathrm{g})$. (A) Control group and (B) PC group. Numbered spots were found with an OD change above fivefold (PDQuest software, Bio-Rad, USA) and identified by MS.

90.0\% sensitivity and $90.0 \%$ specificity in differentiating PC patients from healthy subjects (Fig. 2C). In other words, 18 out of $20 \mathrm{OF}$ samples showed true positive or true negative results, based on the combined biomarker examination.

\section{Discussion}

Pancreatic cancer (PC) is an aggressive cancer and ranks third in cancer mortality in Israel and 8th worldwide ${ }^{2,23,24}$. Most PC are diagnosed at a late stage demonstrating the need to establish a simpler, non-invasive, cost effective screening tool for PC such as oral fluids (OF). 


\begin{tabular}{|c|c|c|c|c|c|c|c|}
\hline Serial no & Protein description & Accesion no & MW (kDa) & $\mathrm{PC} / \mathrm{H}$ & $P$ value & No. of PC samples analysed & No. of Healthy samples analysed \\
\hline \multicolumn{8}{|l|}{ A } \\
\hline 2 & Keratin, type I cytoskeletal 17 & Q04695 & 48.11 & 0.25 & 0.03 & 8 & 10 \\
\hline 4 & S100-A9 & P06702 & 13.24 & 0.28 & 0.05 & 10 & 10 \\
\hline 5 & Glyceraldehyde-3-phosphate dehydrogenase & P04406 & 36.05 & 0.35 & 0.05 & 9 & 10 \\
\hline 8 & Ubiquitin thioesterase & Q9UGI0 & 80.97 & 0.45 & 0.02 & 7 & 7 \\
\hline 9 & Keratin, type I cytoskeletal 14 & $\mathrm{P} 02533$ & 51.62 & 0.50 & 0.00 & 10 & 10 \\
\hline 10 & keratin complex 1 , acidic & A2A5Y0 & 47.12 & 0.50 & 0.05 & 5 & 7 \\
\hline 11 & Keratin, type II cytoskeletal 5 & P13647 & 62.38 & 0.60 & 0.04 & 10 & 10 \\
\hline 12 & Zinc-alpha-2-glycoprotein & P25311 & 34.26 & 1.63 & 0.03 & 10 & 10 \\
\hline 17 & Kallikrein-6 & Q92876 & 26.86 & 6.63 & 0.03 & 8 & 8 \\
\hline 18 & Thioredoxin domain-containing protein & Q9BRA2 & 13.94 & 7.63 & 0.02 & 8 & 8 \\
\hline 19 & Lactoperoxidase & P22079 & 80.29 & 8.63 & 0.01 & 10 & 9 \\
\hline 20 & Zymogen granule protein 16 homolog $\mathrm{B}$ & Q96DA0 & 22.74 & 9.63 & 0.03 & 10 & 10 \\
\hline \multicolumn{8}{|c|}{ ( } \\
\hline 1 & Beta-actin-like protein 2 & Q562R1 & 42 & 0.10 & 0.04 & 2 & 4 \\
\hline 2 & Apolipoprotein A-I & P02647 & 30.78 & 0.15 & 0.05 & 4 & 6 \\
\hline 3 & Purine nucleoside phosphorylase & P00491 & 32.12 & 0.20 & 0.05 & 5 & 4 \\
\hline 4 & Annexin A1 & P04083 & 38.71 & 0.30 & 0.03 & 5 & 6 \\
\hline 5 & L-lactate dehydrogenase B chain & P07195 & 36.64 & 0.35 & 0.04 & 4 & 6 \\
\hline 12 & Tubulin-specific chaperone A & O75347 & 12.86 & 2.41 & 0.05 & 3 & 4 \\
\hline 13 & Ribonuclease T2 & O00584 & 29.48 & 2.42 & 0.03 & 5 & 5 \\
\hline 14 & Costars family protein & Q9P1F3 & 9.056 & 2.92 & 0.05 & 5 & 4 \\
\hline 15 & Dipeptidyl peptidase 1 & P53634 & 51.85 & 3.12 & 0.03 & 5 & 4 \\
\hline 16 & Ig kappa chain V-III region HAH & P18135 & 14.07 & 3.34 & 0.03 & 5 & 5 \\
\hline 17 & Dynein heavy chain 10 , axonemal & Q8IVF4 & 514.8 & 4.67 & 0.04 & 4 & 5 \\
\hline 18 & Calcium-activated chloride channel regulator 4 & Q14CN2 & 101.3 & 5.59 & 0.04 & 5 & 4 \\
\hline 19 & Proline-rich protein 4 & Q16378 & 15.1 & 9.60 & 0.04 & 4 & 3 \\
\hline
\end{tabular}

Table 2. Individual sample analysis $(n=20)$ by label free $q M S$. A. Proteins identified in at least 6 control and $\mathrm{PC}$ subjects with an average differential expression $(P<0.05)$. B. Proteins with an average differential expression $(P<0.05)$, with no minimum number of subjects.

Proteomic analysis of pooled OF samples. This is the first study (to our knowledge) characterizing the $\mathrm{OF}$ proteome of PC patients. The biomarker candidates identified in our pooled OF samples were compared to previous proteomic studies from other tissues or body fluids. Table 1A summarizes 19 proteins out of 21 with more than threefold changes in expression that were considered as potential biomarkers, details of seven of these proteins are presented below:

i. Histones (P62805, P33778, Q96A08) are strongly alkaline proteins which package and organize the DNA into structural units called nucleosomes. Autoantibodies to this protein found in the serum of PC patients have been suggested as potential biomarkers ${ }^{25,26}$. 

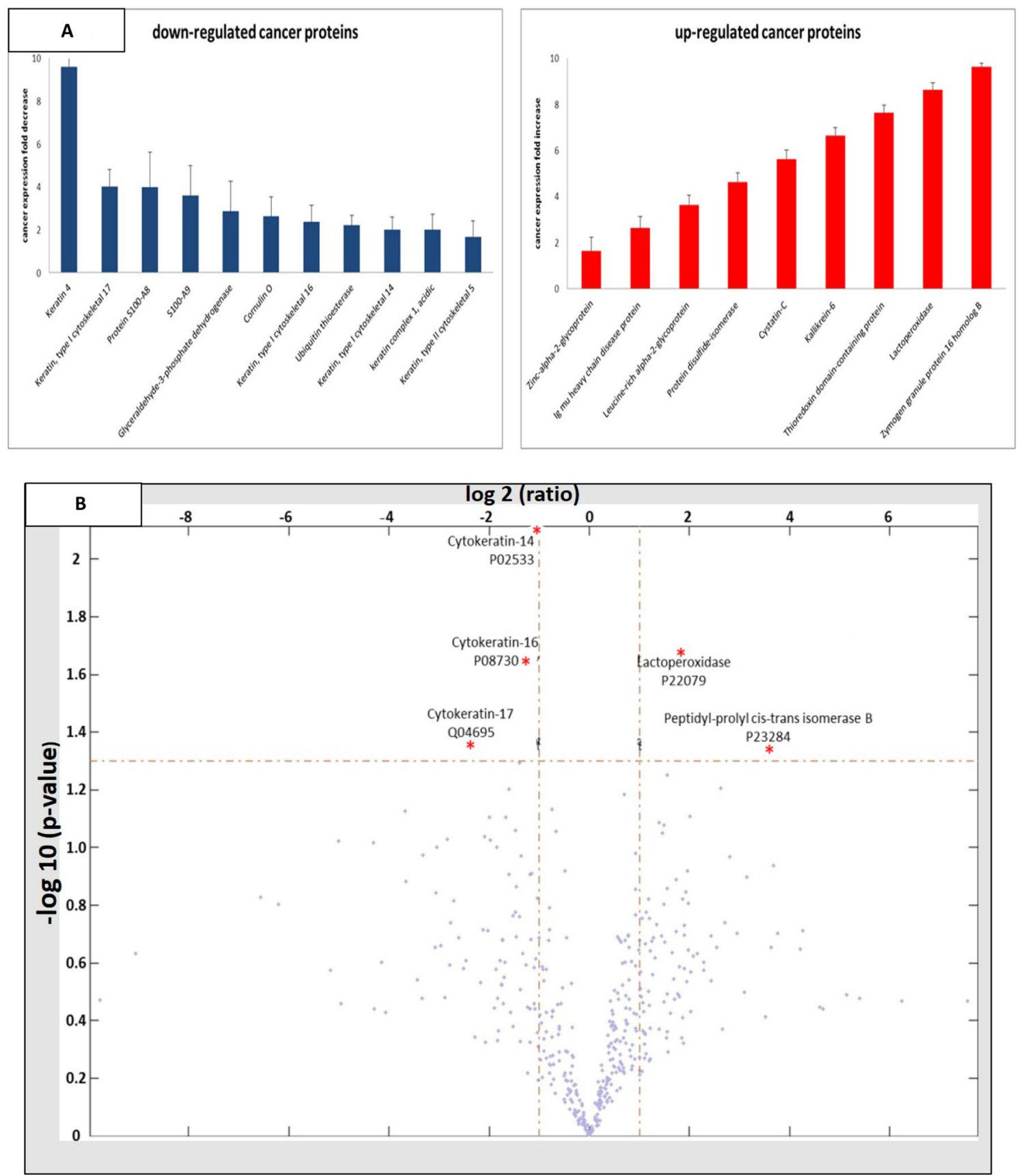

Figure 2. (A) Graphical illustrations of 20 proteins with significantly increased expression $(p<0.05)$ after normalization, found in at least 6 subjects per group. (B). Volcano plot. Red asterisks represent five proteins with the largest statistically significant changes in expression. (C). ROC curve utilizing five biomarkers (P02533, P22079, P08730, Q04695 and P23284) yielded an AUC value of 0.910 , with $90.0 \%$ sensitivity and $90.0 \%$ specificity.

ii. Apolipoprotein A-I precursor has a specific role in lipid metabolism. It is the major component of highdensity lipoprotein in plasma and has recently been patented for early diagnosis, screening, therapeutic follow-up and prognosis, as well as diagnosis of relapse of colorectal cancer ${ }^{27}$.

iii. Myeloperoxidase is an important factor influencing oxygen dependent mechanisms of pathogen destruction. A significant decrease in the activity of myeloperoxidase has been found in the neutrophils of PC patients ${ }^{28}$.

iv. Transthyretin precursor is a serum and cerebrospinal fluid carrier of the thyroid hormone thyroxine (T4) and retinol. Its expression was significantly lower (7.9-fold) in the serum of PC patients ${ }^{29}$.

v. Lipocalin-1 and Protein S100-A8 were down regulated in PC versus non-neoplastic ductal cells by stable isotope labeling with amino acids in cell culture ${ }^{30}$. 
vi. Transketolase is up regulated in PC cells compared to healthy pancreatic ducts (3.66-fold increase compared to the 3.18-fold increase we found in OF) ${ }^{31}$.

vii. Hemopexin is the highest affinity heme binding protein, protecting the body from the oxidative damage that free heme can cause. This protein has been consistently associated with tumors ${ }^{30}$.

Partial overlap between the two-proteomic screening approaches; 2DE and dimethylation qMS demonstrated the importance of employing different proteomic strategies to maximize identification abilities. The disadvantages of 2DE as a proteomic method including: spots containing more than one protein; limited dynamic range imposed by the gel method; difficulty with hydrophobic proteins; inability to detect proteins with extreme molecular weights and $\mathrm{pI}$ values, have been previously described ${ }^{30}$. In order to overcome these limitations, multiple detection methods were used. Furthermore, when a discrepancy was noted between the methods, the label-free qMS on individual samples supported the results of the 2DE upon dimethylation qMS. Nevertheless, the need for extensive individual proteomic analyses and validation is clear.

Bioinformatic analysis. Up and down regulated biomarker candidates were analyzed and clustered according to their molecular and biological functions using David-Kegg Bioinformatics Resources ${ }^{32}$. The expression of 32 proteins increased and 65 had lower levels (>twofold change). The main functional and molecular groups included; signal peptides, glycosylation processes and protease activity (Fig. 3A). These finding are in accordance with extensive bioinformatic analysis of PC biomarker candidates from tumor tissue or patient serum samples ${ }^{33}$. Further analysis utilizing "String" bioinformatics website (http://string-db.org/) to explore protein-protein interaction strength revealed four clustered functional groups, including; tissue homeostasis, regulation of biological quality, peptidase regulation activity and extra cellular exosome (Fig. 3B).

In this study 25 out of 32 candidate biomarkers were exosomal proteins. This, most interestingly, is in full agreement with a study by Lau et al. discussing the role of tumor-derived exosomes in OF biomarker development ${ }^{34}$. The authors, however, focused on the influence of pancreatic exosomes on OF biomarker development, while the role of the exosomes in the targeted organs remained ambiguous. A partial explanation may be that exosomes not only transport messenger molecules from the pancreas to the salivary glands, but also deliver biomarkers to OF. Whether these are the original pancreatic exosomes or newly secreted vesicles from the salivary glands, should be examined further.

Similarly, an in vitro examination showed that breast cancer derived exosomes interact with the salivary glands and alter the composition of salivary gland cell-derived exosome-like macrovesicles in the transcriptome and proteome ${ }^{35}$.

Because a solitary biomarker is unlikely to detect a particular cancer with high specificity and sensitivity, we evaluated combinations of the identified biomarkers using an ROC analysis. We calculated high ROC AUC values indicating that the predictive utility increased substantially, enabling the identification of a group of five biomarker candidates. Three Cytokeratin types (14, 16 and 17), involved in the regulation of cellular properties and functions, including apico-basal polarization, motility, cell size, protein synthesis and membrane traffic and signaling were selected. In many cases, their presence or absence has prognostic significance for cancer patients ${ }^{36}$. The role of cytokeratins in pancreatic cancer and the ability to utilize them as biomarkers is widely discussed in the literature ${ }^{37,38}$. For example Keratin 17 was proven to be a novel negative prognostic biomarker for pancreatic cancer ${ }^{39}$.

The remaining two proteins with elevated levels in OF of PC patients and included in our biomarker combination were Lactoperoxidase and Peptidyl-prolyl cis-trans isomerase B. The latter is also called Cyclophilin $\mathrm{B}(\mathrm{CypB})$ and is a $21-\mathrm{kDa}$ protein belonging to the cyclophilin family of peptidyl-prolyl cis-trans isomerase. It promotes alterations in protein conformation and influences cell growth, proliferation, and motility ${ }^{40}$.

Enhanced expression of CypB in malignant breast epithelium may contribute to the pathogenesis of the disease $^{41}$. Moreover, elevated levels of CypB have been found in sera of PC patients and this protein has been suggested as a serum biomarker for $\mathrm{PC}^{42}$.

The comparison of pooled sample results to individual qMS analysis showed partial overlap. Approximately $33 \%$ of the proteins with the highest expression fold change and lowest p-value identified in the individual samples presented similar expression trends in pooled samples.

Furthermore, $\mathrm{CypB}$, one of the five discriminative biomarkers found in the individual qMS analysis, was related to the down regulation of two S100 proteins. Both the pooled and individual qMS analysis showed decreased expression levels in these proteins. It was previously claimed that pooling serum samples may cause $\mathrm{a} \sim 50 \%$ loss of potential biomarkers ${ }^{43}$. The results of the current study support this argument; yet also show the advantages of the pooling strategy as an initial step before performing extensive examinations on individual samples. Pooled sample analysis enabled a relatively low-cost and rapid "proof of concept" examination. Clearly, validation using individual samples is required to understand the diagnostic potential of the biomarker combination.

\section{Concluding remarks}

Enhanced proteomic characterization of the oral fluids of PC patients revealed a profile of differentially expressed proteins. Bioinformatic analysis of OF was in accordance with previous studies of proteins expressed in PC in tissues, pancreatic juice or serum. Moreover, an extensive label free qMS analysis revealed a group of proteins, which may be used as a highly specific, and sensitive OF based test for PC test. A larger study is required for A. Exploring the accuracy of the combined 5 biomarkers that were found in this study, utilizing different proteomic technology (e.g. Elisa, Western blot, lateral flow immunoassay etc.).

B. validation and identifying high-risk groups in order to enable an early diagnosis, screening, therapeutic follow-up and prognosis and diagnosis of relapse in relation to PC using OF. 
A

cytoskeleton

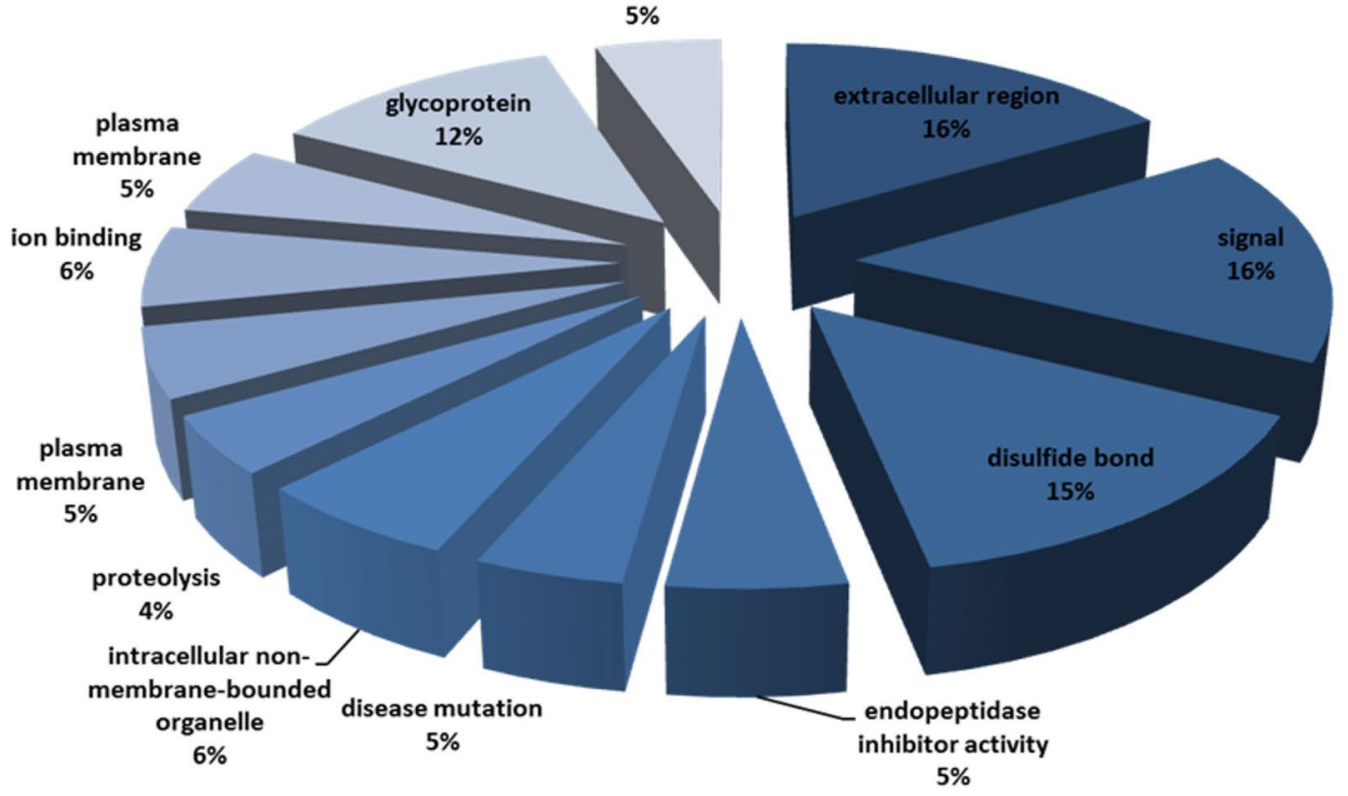

B
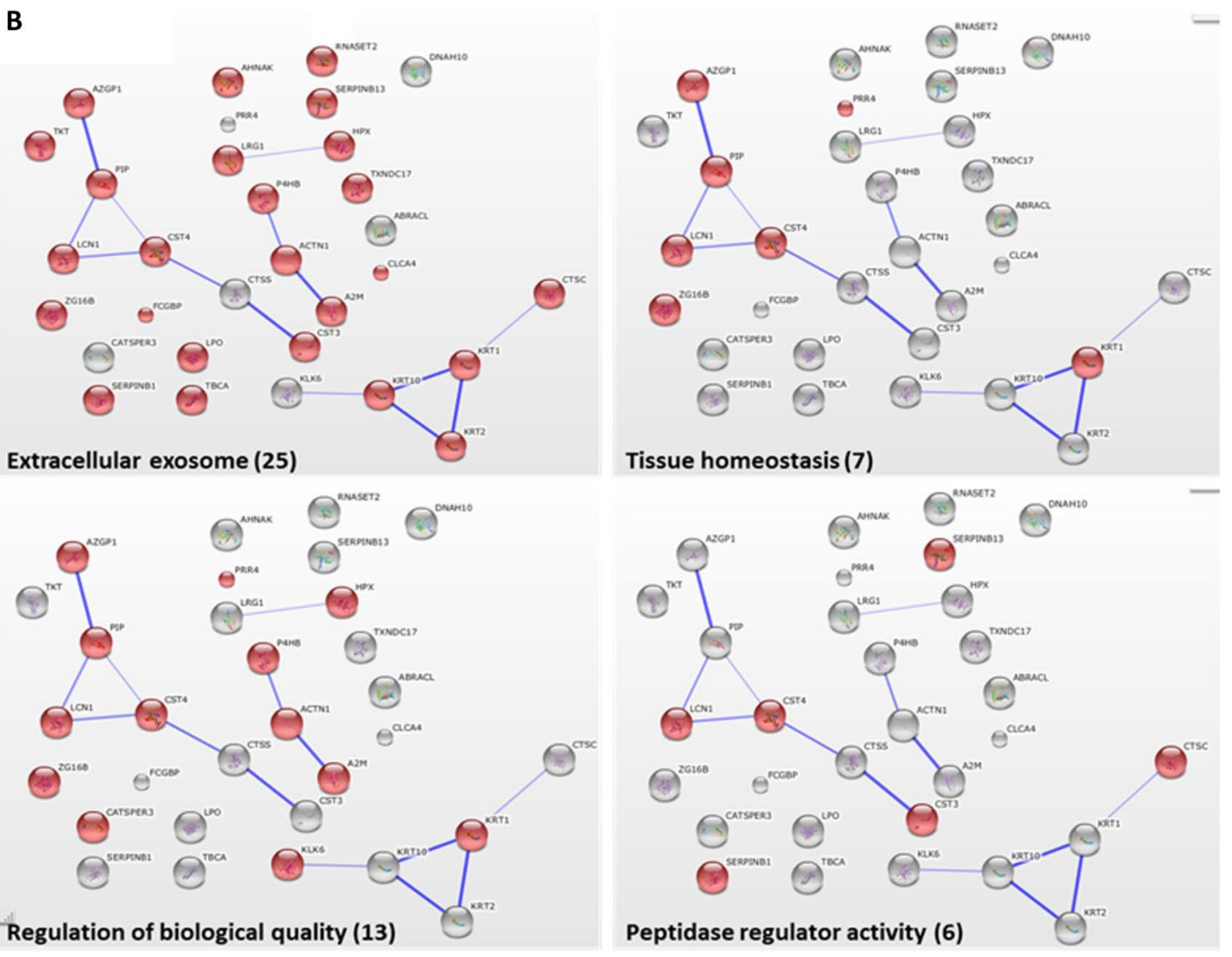

Figure 3. (A) David-Kegg Bioinformatics Resources ${ }^{32}$. Classification of proteins with increased expression according to their biological functions. Proteins with more than one biological function were counted multiple times. (B) "String" online database (http://string-db.org/). Association network of overexpressed proteins in OF of PC patients. 
Received: 1 March 2020; Accepted: 24 November 2020

Published online: 15 December 2020

\section{References}

1. Malvezzi, M. et al. European cancer mortality predictions for the year 2016 with focus on leukaemias. Ann. Oncol. 27, 725-731. https://doi.org/10.1093/annonc/mdw022mdw022 (2016).

2. Parkin, D. M., Bray, F., Ferlay, J. \& Pisani, P. Global cancer statistics, 2002. CA Cancer J. Clin. 55, 74-108. https://doi.org/10.3322/ canjclin55/2/74 (2005).

3. Siegel, R., Naishadham, D. \& Jemal, A. Cancer statistics, 2012. CA Cancer J. Clin. 62, 10-29. https://doi.org/10.3322/caac.20138 (2012).

4. Siegel, R., Naishadham, D. \& Jemal, A. Cancer statistics, 2013. CA Cancer J. Clin. 63, 11-30. https://doi.org/10.3322/caac.21166 (2013).

5. Greabu, M. et al. Saliva-a diagnostic window to the body, both in health and in disease. J. Med. Life 2, 124-132 (2009).

6. Loo, J. A., Yan, W., Ramachandran, P. \& Wong, D. T. Comparative human salivary and plasma proteomes. J. Dent Res. 89, 10161023. https://doi.org/10.1177/0022034510380414 (2010).

7. Krief, G. et al. Proteomic profiling of whole-saliva reveals correlation between Burning Mouth Syndrome and the neurotrophin signaling pathway. Sci. Rep. 9, 4794. https://doi.org/10.1038/s41598-019-41297-9 (2019).

8. Segal, A. \& Wong, D. T. Salivary diagnostics: enhancing disease detection and making medicine better. Eur. J. Dent. Educ. 12(Suppl 1), 22-29. https://doi.org/10.1111/j.1600-0579.2007.00477.x (2008).

9. Vitorino, R. et al. Identification of human whole saliva protein components using proteomics. Proteomics 4, 1109-1115. https:// doi.org/10.1002/pmic.200300638 (2004).

10. Hu, S., Loo, J. A. \& Wong, D. T. Human saliva proteome analysis. Ann. N. Y. Acad. Sci. 1098, 323-329. https://doi.org/10.1196/ annals.1384.015 (2007).

11. Oppenheim, F. G., Salih, E., Siqueira, W. L., Zhang, W. \& Helmerhorst, E. J. Salivary proteome and its genetic polymorphisms. Ann. N. Y. Acad. Sci. 1098, 22-50. https://doi.org/10.1196/annals.1384.030 (2007).

12. Hu, S. et al. Salivary proteomics for oral cancer biomarker discovery. Clin. Cancer Res. 14, 6246-6252. https://doi.org/10.1158/10780432.CCR-07-5037 (2008).

13. $\mathrm{Hu}$, S. et al. Large-scale identification of proteins in human salivary proteome by liquid chromatography/mass spectrometry and two-dimensional gel electrophoresis-mass spectrometry. Proteomics 5, 1714-1728. https://doi.org/10.1002/pmic.200401037 (2005).

14. Deutsch, O. et al. An approach to remove alpha amylase for proteomic analysis of low abundance biomarkers in human saliva. Electrophoresis 29, 4150-4157. https://doi.org/10.1002/elps.200800207 (2008).

15. Krief, G. et al. Improved visualization of low abundance oral fluid proteins after triple depletion of alpha amylase, albumin and IgG. Oral. Dis. 17, 45-52. https://doi.org/10.1111/j.1601-0825.2010.01700.x (2011).

16. Krief, G. et al. Comparison of diverse affinity based high-abundance protein depletion strategies for improved bio-marker discovery in oral fluids. J. Proteom. 75, 4165-4175. https://doi.org/10.1016/j.jprot.2012.05.012 (2012).

17. Streckfus, C. \& Bigler, L. The use of soluble, salivary c-erbB-2 for the detection and post-operative follow-up of breast cancer in women: the results of a five-year translational research study. Adv. Dent. Res. 18, 17-24 (2005).

18. Aframian, D. J., Davidowitz, T. \& Benoliel, R. The distribution of oral mucosal $\mathrm{pH}$ values in healthy saliva secretors. Oral Dis. 12, 420-423. https://doi.org/10.1111/j.1601-0825.2005.01217.x (2006).

19. Bradford, M. M. A rapid and sensitive method for the quantitation of microgram quantities of protein utilizing the principle of protein-dye binding. Anal. Biochem. 72, 248-254. https://doi.org/10.1016/0003-2697(76)90527-3 (1976).

20. Bjellqvist, B., Pasquali, C., Ravier, F., Sanchez, J. C. \& Hochstrasser, D. A nonlinear wide-range immobilized pH gradient for twodimensional electrophoresis and its definition in a relevant $\mathrm{pH}$ scale. Electrophoresis 14, 1357-1365 (1993).

21. Beer, I., Barnea, E., Ziv, T. \& Admon, A. Improving large-scale proteomics by clustering of mass spectrometry data. Proteomics 4, 950-960. https://doi.org/10.1002/pmic.200300652 (2004).

22. Zhang, L. et al. Salivary transcriptomic biomarkers for detection of resectable pancreatic cancer. Gastroenterology 138, 949-957. https://doi.org/10.1053/j.gastro.2009.11.010 (2010).

23. Jemal, A. et al. Cancer statistics, 2009. CA Cancer J. Clin. 59, 225-249. https://doi.org/10.3322/caac.20006 (2009).

24. Jemal, A., Siegel, R., Xu, J. \& Ward, E. Cancer statistics, 2010. CA Cancer J. Clin. 60, 277-300. https://doi.org/10.3322/caac.20073 (2010).

25. Patwa, T. H. et al. The identification of phosphoglycerate kinase- 1 and histone $\mathrm{H} 4$ autoantibodies in pancreatic cancer patient serum using a natural protein microarray. Electrophoresis 30, 2215-2226. https://doi.org/10.1002/elps.200800857 (2009).

26. Kamei, M. et al. Serodiagnosis of cancers by ELISA of anti-histone H2B antibody. Biotherapy 4, 17-22 (1992).

27. 27Ataman-Onal, Y., Charrier, J. P., Choquet-Kastylevsky, G. \& Poirier, F. (Google Patents, 2014).

28. Geetha, A., Jeyachristy, S. A. \& Surendran, R. Assessment of immunity status in patients with pancreatic cancer. J. Clin. Biochem. Nutr. 39, 18-26 (2006).

29. Yu, K. H., Rustgi, A. K. \& Blair, I. A. Characterization of proteins in human pancreatic cancer serum using differential gel electrophoresis and tandem mass spectrometry. J. Proteome Res. 4, 1742-1751. https://doi.org/10.1021/pr050174l (2005).

30. Gronborg, M. et al. Biomarker discovery from pancreatic cancer secretome using a differential proteomic approach. Mol. Cell Proteom. 5, 157-171. https://doi.org/10.1074/mcp.M500178-MCP200 (2006).

31. Cui, Y. et al. Proteomic and tissue array profiling identifies elevated hypoxia-regulated proteins in pancreatic ductal adenocarcinoma. Cancer Invest. 27, 747-755. https://doi.org/10.1080/07357900802672746 (2009).

32. Huang, D. W., Brad, S. T. \& Lempicki, R. A. Systematic and integrative analysis of large gene lists using DAVID Bioinformatics Resources. Nat. Protoc. 4, 44-57 (2009).

33. Grutzmann, R. et al. Meta-analysis of microarray data on pancreatic cancer defines a set of commonly dysregulated genes. Oncogene 24, 5079-5088. https://doi.org/10.1038/sj.onc.1208696 (2005).

34. Lau, C. et al. Role of pancreatic cancer-derived exosomes in salivary biomarker development. J. Biol. Chem. https://doi.org/10.1074/ jbc.M113.452458 (2013).

35. Lau, C. S. \& Wong, D. T. Breast cancer exosome-like microvesicles and salivary gland cells interplay alters salivary gland cell-derived exosome-like microvesicles in vitro. PLoS ONE 7, e33037. https://doi.org/10.1371/journal.pone.0033037 (2012).

36. Karantza, V. Keratins in health and cancer: more than mere epithelial cell markers. Oncogene 30, 127-138 (2011)

37. Goldstein, N. S. \& Bassi, D. Cytokeratins 7, 17, and 20 reactivity in pancreatic and ampulla of vater adenocarcinomas. Percentage of positivity and distribution is affected by the cut-point threshold. Am. J. Clin. Pathol. 115, 695-702. https://doi.org/10.1309/1NCM46QX-3B5T-7XHR (2001).

38. Poruk, K. E. et al. Circulating tumor cells expressing markers of tumor-initiating cells predict poor survival and cancer recurrence in patients with pancreatic ductal adenocarcinoma. Clin. Cancer Res Offic. J. Am. Assoc. Cancer Res. 23, 2681-2690. https://doi. org/10.1158/1078-0432.CCR-16-1467 (2017).

39. Roa-Pena, L. et al. Keratin 17 identifies the most lethal molecular subtype of pancreatic cancer. Sci. Rep. 9, 11239. https://doi. org/10.1038/s41598-019-47519-4 (2019). 
40. Price, E. R. et al. Human cyclophilin B: a second cyclophilin gene encodes a peptidyl-prolyl isomerase with a signal sequence. Proc. Natl. Acad. Sci. USA 88, 1903-1907 (1991).

41. Fang, F., Flegler, A. J., Du, P., Lin, S. \& Clevenger, C. V. Expression of cyclophilin B is associated with malignant progression and regulation of genes implicated in the pathogenesis of breast cancer. Am. J. Pathol. 174, 297-308. https://doi.org/10.2353/ajpat h.2009.080753 (2009).

42. Ray, P., Rialon-Guevara, K. L., Veras, E., Sullenger, B. A. \& White, R. R. Comparing human pancreatic cell secretomes by in vitro aptamer selection identifies cyclophilin B as a candidate pancreatic cancer biomarker. J. Clin. Invest. 122, 1734-1741. https://doi. org/10.1172/JCI62385 (2012).

43. Sadiq, S. T. \& Agranoff, D. Pooling serum samples may lead to loss of potential biomarkers in SELDI-ToF MS proteomic profiling. Proteome Sci. 6, 16 (2008).

\section{Acknowledgements}

There were no funding and no publishable conflicts of interest for this work.

\section{Author contributions}

D.O, K.G, Z.B, W.R, L.O, N.S, Y.R and P.A made substantial contributions to the study's conception and design, acquisition of data, lab working and analysis and interpretation of data; S.S, D.O and W.R were in charge on sample collection. H.Y, A.JD, D,O and L.O drafted the submitted article and provided critical interpretation. H.Y, D.O and K.N wrote, revised and approved the manuscript. All authors discussed the results and commented on the manuscript.

\section{Competing interests}

The authors declare no competing interests.

\section{Additional information}

Supplementary Information The online version contains supplementary material available at (https://doi. org/10.1038/s41598-020-78922-x).

Correspondence and requests for materials should be addressed to A.P.

Reprints and permissions information is available at www.nature.com/reprints.

Publisher's note Springer Nature remains neutral with regard to jurisdictional claims in published maps and institutional affiliations.

(c) (i) Open Access This article is licensed under a Creative Commons Attribution 4.0 International License, which permits use, sharing, adaptation, distribution and reproduction in any medium or format, as long as you give appropriate credit to the original author(s) and the source, provide a link to the Creative Commons licence, and indicate if changes were made. The images or other third party material in this article are included in the article's Creative Commons licence, unless indicated otherwise in a credit line to the material. If material is not included in the article's Creative Commons licence and your intended use is not permitted by statutory regulation or exceeds the permitted use, you will need to obtain permission directly from the copyright holder. To view a copy of this licence, visit http://creativecommons.org/licenses/by/4.0/.

(c) The Author(s) 2020 